\section{A Rapid and Simple Method for Reversing the Inhibitory Effect of Heparin on PCR for HLA Class II Typing}

\author{
Francesca Poli, \\ Rosa Cattaneo, \\ Loretta Crespiatico, \\ Angela Nocco, and \\ Girolamo Sirchia
}

Centro Trasfusionale e di Immunologia dei Trapianti, Ospedale Maggiore Policlinico, 20122 Milan, Italy
Blood samples collected with heparin as anticoagulant have been shown to yield decreased quantities of DNA, and an inhibitory effect of this anticoagulant on PCR has been demonstrated. Furthermore, in our experience, the amplification by PCR of HLA-DRB1 second exon was unsuccessful when the DNA template was obtained from heparinized blood. In this paper a simple method for eliminating the inhibitory effect of heparin on Taq polymerase is described. It employs a chelating ion resin, and DNA obtained can be used successfully for PCR and for HLA class II sequence-specific oligonucleotide (SSO) typing. This method, validated on $>600$ typings, is a useful alternative when no other source of DNA, except for heparinized blood, is available.

Since 1989 we have been storing peripheral blood from donors and graft recipients in liquid nitrogen at $-40^{\circ} \mathrm{C}$ to perform retrospective studies. With DNA technology, we began to re-evaluate the role of HLA class II matching by sequence-specific oligonucleotide typing (SSO typing) after DNA amplification by PCR. Most of the samples stored consisted of heparinized blood, as we were unaware of the inhibitory effect of this anticoagulant on several DNA polymerases. ${ }^{(1,2)}$ As a consequence, a significant number of samples could not be amplified by PCR and typed at the gene level. To overcome this problem, the use of heparinase has been suggested ${ }^{(2,3)}$ but it is costly and sometimes fails. ${ }^{(2)}$

To reverse the inhibitory effect of heparin on Taq polymerase we used Chelex 100 , an ion-exchange resin (Bio-Rad Laboratories, Richmond, CA). This agent is usually employed in our laboratory to improve the quality of DNA for $\mathrm{PCR}^{(4)}$ and by others in a variety of PCR situations. ${ }^{(5)}$ Here, we report our experience with the use of this resin both for "cleaning" DNA extracted from heparinzed blood, which previously failed to amplify by PCR, as well as for DNA extraction. The amplified DNA was employed for genomic HLA class II typing. The interaction mechanism between Chelex 100 and heparin has also been investigated.

\section{MATERIALS AND METHODS}

\section{Samples}

Samples of DNA extracted from heparin- ized blood using standard chloroform/ ethanol procedures, the amplification of which was previously found to be ineffective, and frozen samples of heparinized blood from organ donors and recipients were selected for Chelex 100 treatment. Because the blood samples had not been drawn in our laboratory, the number of heparin units was unknown and they varied from sample to sample.

\section{DNA Cleaning}

A $180-\mu l$ aliquot of $5 \%$ Chelex 100 (wt/ vol) was added to $0.1-0.2 \mu \mathrm{g}$ of DNA in $20 \mu \mathrm{l}$ of distilled water, and the mixture was incubated in a water bath at $56^{\circ} \mathrm{C}$ for $20 \mathrm{~min}$. Subsequently, the mixture was vortexed and boiled for $8 \mathrm{~min}$. After a 3 -min spin at $12,000 \mathrm{~g}$ to eliminate the resin, $20 \mu \mathrm{l}$ of the supernatant was used per 100- $\mu$ l PCR reaction.

\section{DNA Extraction with Chelex 100}

After thawing, $4 \mu \mathrm{l}$ of heparinized blood was added to $1 \mathrm{ml}$ of distilled water into a sterile $1.5-\mathrm{ml}$ microcentrifuge tube. The mixture was incubated at room temperature for $20 \mathrm{~min}$, with occasional vortexing. After a 3-min spin at $12,000 \mathrm{~g}$, the supernatant was removed and discarded. A $200-\mu \mathrm{l}$ aliquot of $5 \%$ Chelex 100 (wt/ vol) was added; the procedure for DNA cleaning described previously was then followed.

\section{Primers and Oligonucleotides}

The DRB1 primers and oligonucleotide probes were synthesized using a Gene Assembler Plus (LKB-Pharmacia); the sequences are reported elsewhere. ${ }^{(6)}$

\section{DNA Amplification}

The incubation mixture for each individual amplification consisted of $20 \mu \mathrm{l}$ of DNA, dNTP mix (final concentration 200 $\mu \mathrm{M}$ of each nucleotide), 20 pmoles of both the upstream $\left(5^{\prime}\right)$ primer and the downstream $\left(3^{\prime}\right)$ primer, $10 \mu \mathrm{l}$ of PCR buffer $[500 \mathrm{~mm} \mathrm{KCl}, 100 \mathrm{~mm}$ Tris- $\mathrm{HCl}$ ( $\mathrm{pH} \mathrm{8.4)}$ at room temperature, $40 \mathrm{~mm}$ $\mathrm{MgCl}_{2}$, and $0.6 \mathrm{mg} / \mathrm{ml}$ of $\left.\mathrm{BSA}\right]$ and 2 units of heat-stable $\mathrm{Taq}$ polymerase (Perkin-Elmer Cetus, Emeryville, CA). The final volume of the incubation mixture was brought to $100 \mu \mathrm{l}$ using sterile distilled water. The amplification took 
place in a Thermocycler (DNA Thermal Cycler, Perkin-Elmer Cetus), with the following amplification profile used routinely in our laboratory, that is, $30 \mathrm{sec}$ at $97^{\circ} \mathrm{C}, 30 \mathrm{sec}$ at $55^{\circ} \mathrm{C}, 30 \mathrm{sec}$ at $72^{\circ} \mathrm{C}$, and $30 \mathrm{sec}$ at $97^{\circ} \mathrm{C}$. After 35 cycles, a final extension step for $10 \mathrm{~min}$ at $72^{\circ} \mathrm{C}$ was performed.

\section{Gel Analysis of Amplified DNA}

The efficiency of PCR was assessed by resolving $5 \mu \mathrm{l}$ of the amplification products by $2 \%$ agarose gel electrophoresis as a single ethidium bromide-stained band of $\sim 290 \mathrm{bp}$.

\section{Dot Blot Preparation, Hybridization, and Washing Conditions}

Dot blot preparation, hybridization with 5'-end, ${ }^{32}$ P-labeled oligonucleotide probes, and washing conditions were those described by Giphart and Verduijn ${ }^{(6)}$ with slight modifications. Briefly, 5 $\mu \mathrm{l}$ of PCR products was added to $100 \mu \mathrm{l}$ of denaturation buffer $(0.4 \mathrm{M} \mathrm{NaOH}, 10$ mM EDTA) for each dot produced, and then dot blotted onto a nylon membrane (Zeta-Probe, Bio-Rad) using a dot blot apparatus (Hybri Dot Manifold, BRL, Life Technologies, Inc., Gaithersburg, MD). Prehybridization consisted of $60 \mathrm{~min}$ at $54^{\circ} \mathrm{C}$, and hybridization for 3 $\mathrm{hr}$ at the same temperature in the hybridization buffer containing the 5 '-end, ${ }^{32}$ P-labeled oligonucleotide probe.

Hybridization buffer consisted of $3 \mathrm{M}$ (TMACl), $50 \mathrm{~mm}$ Tris- $\mathrm{HCl}$ (pH 7.5), $5 \mathrm{~mm}$ EDTA, $1 \%$ SDS, and $100 \mu \mathrm{g} / \mathrm{ml}$ of denatured salmon sperm DNA. Blots were rinsed briefly in $2 \times$ SSC, $1 \%$ SDS, and washed twice with the same solution at room temperature for $10 \mathrm{~min}$. The membranes were then washed with $3 \mathrm{~m}$ TMACl, $50 \mathrm{~mm}$ Tris-HCl (pH 7.5), $5 \mathrm{~mm}$ EDTA, and $1 \%$ SDS once at room temperature and twice at $60^{\circ} \mathrm{C}$. Washing conditions were the same for all the oligonucleotide probes used, which allowed typing of the most important HLA-DR specificities. The reactivity pattern of the probes used is described elsewhere. ${ }^{(6)}$

\section{Evaluation of Heparin/Chelex 100 Interaction}

To evaluate the interaction mechanism of Chelex 100 with heparin, two experiments were carried out: (1) The original untreated DNA extracts that failed to amplify were added back to the Chelex 100 cleaned samples and retested for PCR amplification; and (2) heparin (1500 units; Liquemin Roche) was incubated with $500 \mathrm{mg}$ of Chelex 100 at $56^{\circ} \mathrm{C}$ for 30 $\mathrm{min}$. Then, $3.5 \mu \mathrm{l}(14.3 \mathrm{U} / \mathrm{ml}$ of peripheral blood) of the absorbed heparin was tested for anticoagulant activity.

\section{RESULTS}

\section{DNA Amplification of DRB1 Second Exon}

In every instance, cleaned DNA and DNA isolated from heparinized blood with Chelex 100 were efficiently amplified by PCR. In contrast, DNA extracted from the same heparinized samples with standard chloroform/ethanol procedures always failed to amplify (Fig. 1).

\section{Evaluation of Heparin/Chelex 100 Interaction}

When original DNA extracts were added back to the samples cleaned with Chelex 100 , we observed inhibition of the restored PCR capabilities, that is, samples failed to amplify. The preincubation of heparin with Chelex 100 did not affect the anticoagulant activity.

\section{DISCUSSION}

Several techniques for genomic HLA class II typing depend on the capability of amplifying polymorphic regions of class II genes. Although PCR is highly effective in amplifying DNA obtained from any nucleated cell and from a small amount of material, it may be unsuccessful when the source of DNA is heparinized blood because heparin competitively inhibits several cellular DNA polymerases; ${ }^{(7)}$ among these is Taq polymerase, ${ }^{(2,7)}$ which is commonly employed in PCR technology. This is the result of an affinity between heparin and polymerases $^{(8-10)}$ which makes the latter unavailable for PCR. Heparin can be exploited in the purification of DNA and RNA polymerases by affinity chromatography on heparin-Sepharose. ${ }^{(8-10)}$ The addition of heparinase during PCR gives only a modest reversal of the inhibitory effect; moreover, heparinase is a costly reagent.

We have shown here that the use of Chelex 100 can overcome the problem of the presence of heparin in PCR. This method has been used successfully in all cases for which only heparinizied blood was available as the source of DNA. This method is simple as well as fast; DNA extraction can be completed in $<1 \mathrm{hr}$. Moreover, it is less expensive than the other available methods.

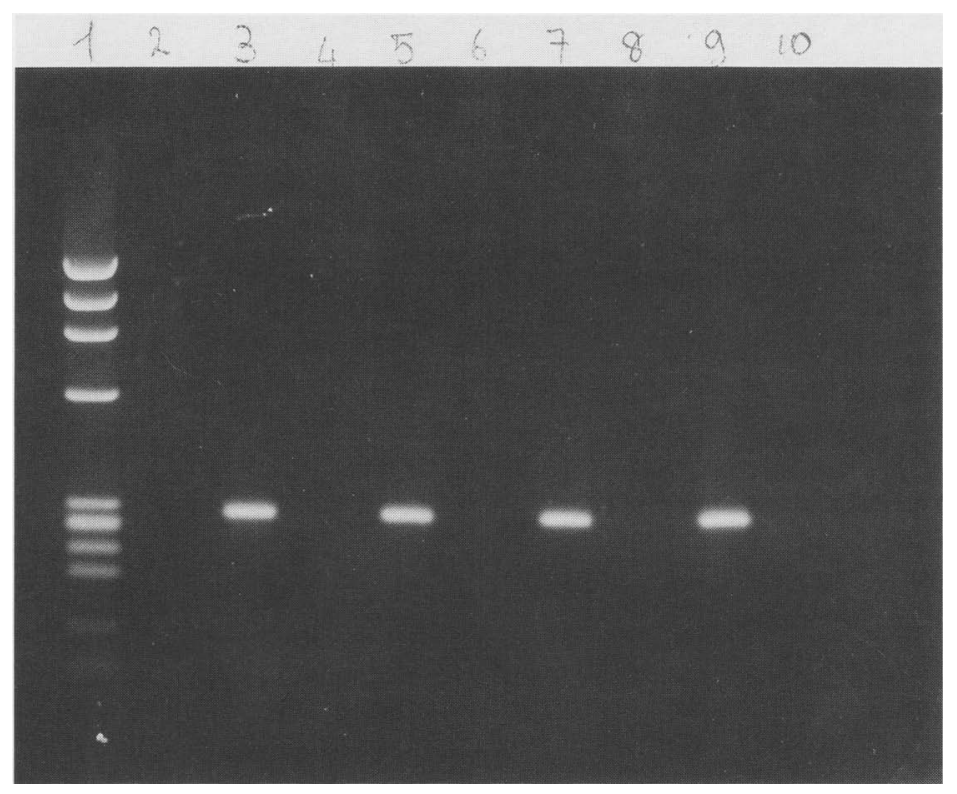

FICURE 1 The results of PCR amplification of HLA-DRB1 second exon with template DNA from four different samples extracted with Chelex 100 (lanes 3,5,7,9) and standard chloroform/ethanol procedure (lanes $4,6,8,10$ ). Observe the absence of amplification in lanes $4,6,8,10$. (Lane 1) Molecular size marker; (lane 2) negative control. 
The precise mechanism by which Chelex 100 prevents heparin from interfering with Taq polymerase remains unclear from our experiments; however, a trapping mechanism by Chelex 100 , or a chemical interaction, seems unlikely as the absorbed herparin maintains its anticoagulant activity. In our opinion, an indirect mechanism seems more probable. Heating under alkaline conditions (Chelex 100 is pH 10.8 at room temperature), for instance, may help to assure complete denaturation of DNA template and increase PCR signal.

At this time, the technique reported here has been validated on $>600$ PCR amplifications and HLA class II typings. The efficiency of this technique is the same in transplant recipients and cadaver donors.

\section{ACKNOWLEDGMENT}

We are very grateful to Dr. Luca Ruocco for his valuable suggestions.

\section{REFERENCES}

1. Beutler, E., T. Gelbart, and W. Kuhl. 1990. Interference of heparin with the polymerase chain reaction. BioTechniques 9: 166.

2. Holodniy, M., S. Kim, D. Katzenstein, M. Konrad, E. Groves, and T.C. Merigan. 1991. Inhibition of human immunodeficiency virus gene amplification by heparin. J. Clin. Microbiol. 29: 676-679.

3. Martin, M., M. Carrington, and D. Mann. 1992. A method for using serum or plasma as a source of DNA for HLA typing. Hum. Immunol. 33: 108-113.

4. Singer-Sam, J., R.L. Tanguay, and A.D. Riggs. 1989. Use of Chelex to improve the PCR signal from a small number of cells. Amplifications 3: 11.

5. Walsh, P.S., D.A. Metzger, and R. Higuchi. 1991. Chelex 100 as a medium for simple extraction of DNA for PCR-based typing from forensic material. BioTechniques 10: $506-513$.

6. Giphart, M.J. and W. Verduijn. 1991. The Eurotransplant HLA-DRB oligonucleotide typing set. Eur. J. Immunogenet. 18: 5768.

7. Furukawa, K. and V.P. Bhavanandan. 1983. Influences of anionic polysaccharides on DNA synthesis in isolated nuclei and by DNA polymerases $\alpha$ : Correlation of observed effects with properties of the polysaccharides. Biochim. Biophys. Acta 740: $466-475$.

8. Brennessel, B.A., D.P. Buhrer, and A.A. Gottlieb. 1978. Use of insoluble heparin for isolation of DNA polymerase enzymes from murine myeloma. Anal. Biochem. 87: 411-417.

9. Golomb, M., A.C. Vora, and D.P. Grandgenett. 1980. Purification of reverse transcriptase from avian retroviruses using affinity chromatography on heparinsepharose. I. Virol. Methods 1: 157-165.

10. Nasheuer, H.P. and F. Grosse. 1987. Immunoaffinity-purified DNA polymerase alpha displays novel properties. Biochemistry 26: 8458-8466.

Received December 15, 1992; accepted in revised form on February 16, 1993. 


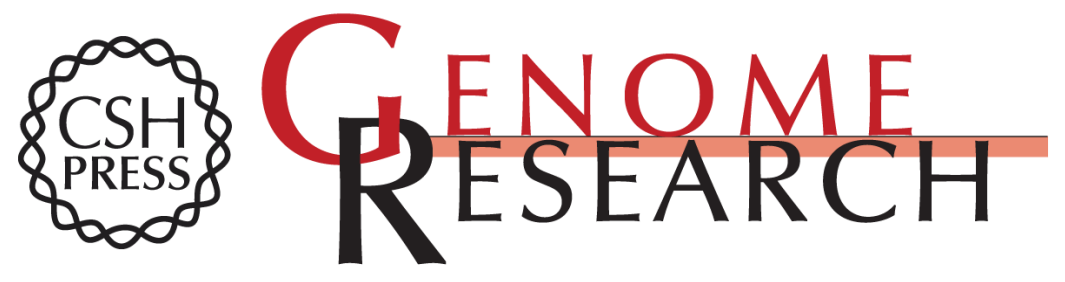

\section{A rapid and simple method for reversing the inhibitory effect of heparin on PCR for HLA class II typing.}

F Poli, R Cattaneo, L Crespiatico, et al.

Genome Res. 1993 2: 356-358

Access the most recent version at doi:10.1101/gr.2.4.356

References This article cites 10 articles, 1 of which can be accessed free at:

http://genome.cshlp.org/content/2/4/356.full.html\#ref-list-1

\section{License}

Email Alerting Receive free email alerts when new articles cite this article - sign up in the box at the Service top right corner of the article or click here.

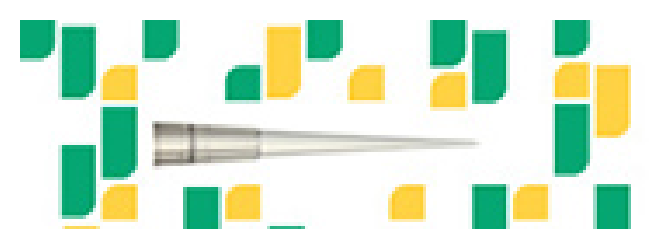

To subscribe to Genome Research go to: https://genome.cshlp.org/subscriptions 